DJS Vol. 42 (1) (2020) pp.45- 57 ISSN: 1012-5965

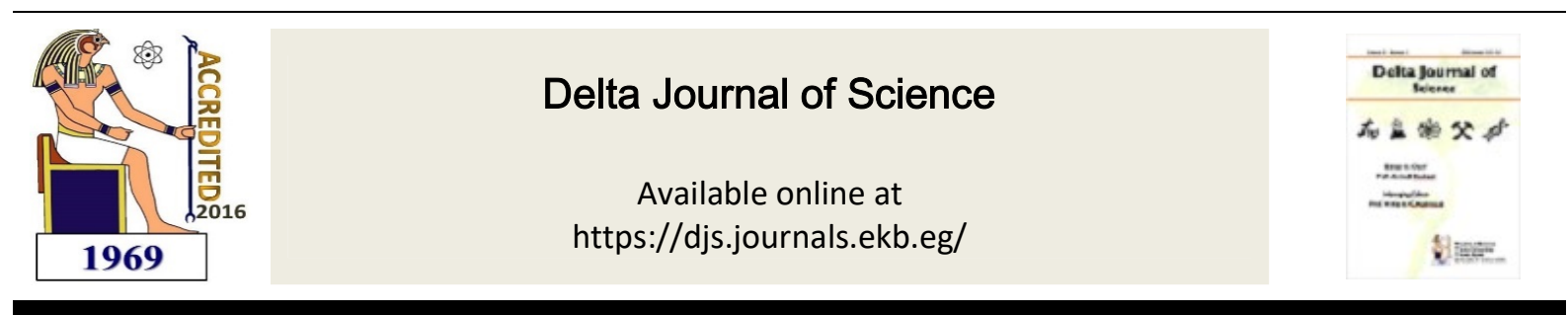

Research Article

GIEOLOGY

\title{
Source Rock Evaluation of Some Mesozoic and Paleozoic Rocks, Faghur Basin, Neith Field, North Western Desert, Egypt
}

\author{
Mai A. El Sherief ${ }^{1^{*}}$, Mohamed A. Elbastawesy ${ }^{2}$, Abdelaziz L. Abdeldayem ${ }^{1}$ and \\ Shadia A. Mohamed ${ }^{1}$ \\ *Corresponding author e-mail address: mai.elsherief@yahoo.com \\ ${ }^{1}$ Geology Department, Faculty of Science, Tanta University, 31527 Tanta, Egypt \\ ${ }^{2}$ Khalda Petroleum Company, New Maadi, P.O Box 560, Maadi, Cairo, Egypt
}

\section{KEY WORDS}

Western Desert, Faghur Basin, Neith Field, Geochemical, Mesozoic, Paleozoic.

\begin{abstract}
Faghur Basin is one of the most important hydrocarbon provinces in the northern Western Desert of Egypt. Some of the Mesozoic (Alam El Bueib and Khatatba formations) and Paleozoic rocks at this basin were evaluated as source rocks based on certain parameters including: the quantity, quality and maturation of the contained organic matter. PetroMode 1D software was used for the construction and prediction of geological and geochemical models. Results from organic geochemical analysis have clarified that the TOC, HI, S1, S2, $\% \mathrm{R}_{\mathrm{o}}$ and $\mathrm{T}_{\max }$ values of Alam El Bueib source rock units range from 0.27 to 6.39 wt. $\%, 34$ to $114 \mathrm{mg} / \mathrm{g}, 0.12$ to $0.38 \mathrm{mg} / \mathrm{g}, 0.23$ to $4.3 \mathrm{mg} / \mathrm{g}, 0.58$ to $1.07 \%$ and 409 to $450{ }^{\circ} \mathrm{C}$, respectively. While for the Khatatba source rock these values range from 0.41 to 30.09 wt. $\%, 27$ to $155 \mathrm{mg} / \mathrm{g}, 0.1$ to $0.53 \mathrm{mg} / \mathrm{g}, 0.15$ to $26.41 \mathrm{mg} / \mathrm{g}, 1.02$ to $1.09 \%, 363$ to $454{ }^{\circ} \mathrm{C}$, respectively. As for the Paleozoic source rock they are ranging from 0.53 to 4.83 wt. $\%, 52$ to $136 \mathrm{mg} / \mathrm{g}, 0.06$ to $0.4 \mathrm{mg} / \mathrm{g}, 0.29$ to $6.57 \mathrm{mg} / \mathrm{g}, 0.97$ to $1.1 \%$ and 406 to $467{ }^{\circ} \mathrm{C}$, respectively. Such results indicate that the Alam El Bueib source rocks are characterized by type (III) kerogen while Khatatba and Paleozoic source rocks are of type (III) kerogen with inputs of kerogen type (II). Burial history analysis indicates that most of these source rocks are mature and reached their maximum temperature at Neogene time.
\end{abstract}

\section{Introduction}

Faghur Basin lies in the northwestern part of the Western Desert of Egypt where numerous oil potentialities may soon jump as a great oil province. This basin is considered as part of Khalda concession, in the northern part of the Western Desert of Egypt. This study focuses on the geochemical characteristics of the source rocks of the Phiops filed that is 
considered as one of the most productive oil fields in the Faghur Basin. As there is no geochemical data available for the Phiops field, data from the Neith S-2X well from the neighbor Neith field within the Faghur basin (Fig. 1) has been used. The Faghur Basin lies at the eastern extent of the Libyan Cyrenaica Platform that is poorly defined and is mainly a plateau area with about $9000 \mathrm{ft}$ thickness of epicontinental Paleozoic strata overlying basement rocks (EGPC, 1992).

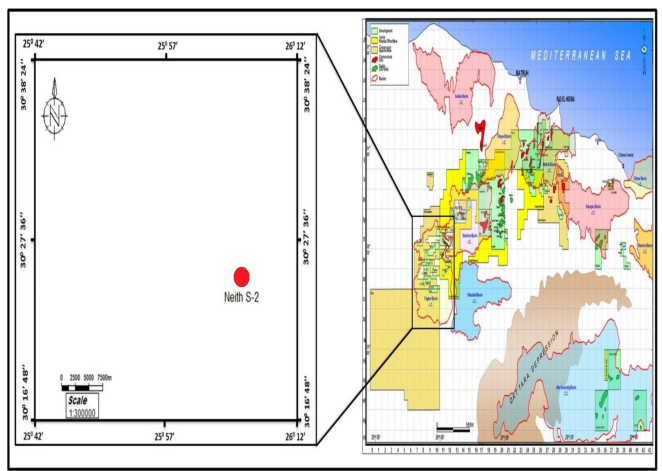

Fig. 1: Location map of Neith S-2X well.

In the present study, geochemical data from the Neith S-2X well in Faghur Basin have been were used for the evaluation of Alam El Bueib, Khatatba, and Paleozoic source rocks. The wide areal distribution, large thickness, and facies characteristics of the subsurface Cretaceous Alam El Bueib and the Jurassic Khatatba sediments have recently attracted the attention of many petroleum geologists (e.g., Carlos et al., 2001; Zein El-Din et al., 2001; Abdou et al., 2009; Shalaby et al., 2013). On the other hand, the Paleozoic rocks of several thousand fts thickness have been reported in the subsurface (Barakat, 1982; El-Dakkak, 1988; Keeley, 1989). An Upper Paleozoic basin is thought to have occupied the area of Faghur (El-Mansey et al., 2004 and Abd-El Gawad et al., 2015, 2016 and 2019).

\section{Geological Setting}

The stratigraphic section in the northern Western Desert (Schlumberger, 1995) ranges in age from Pre-Cambrian-Basement Complex to Recent (Fig. 2). The sedimentary section can be divided into three sequences based on lithology, namely: the lower clastic unit from Cambrian to pre-Cenomanian, the middle carbonate units from Cenomanian to Eocene, and the upper clastic unit from Oligocene to Recent (Said, 1962).

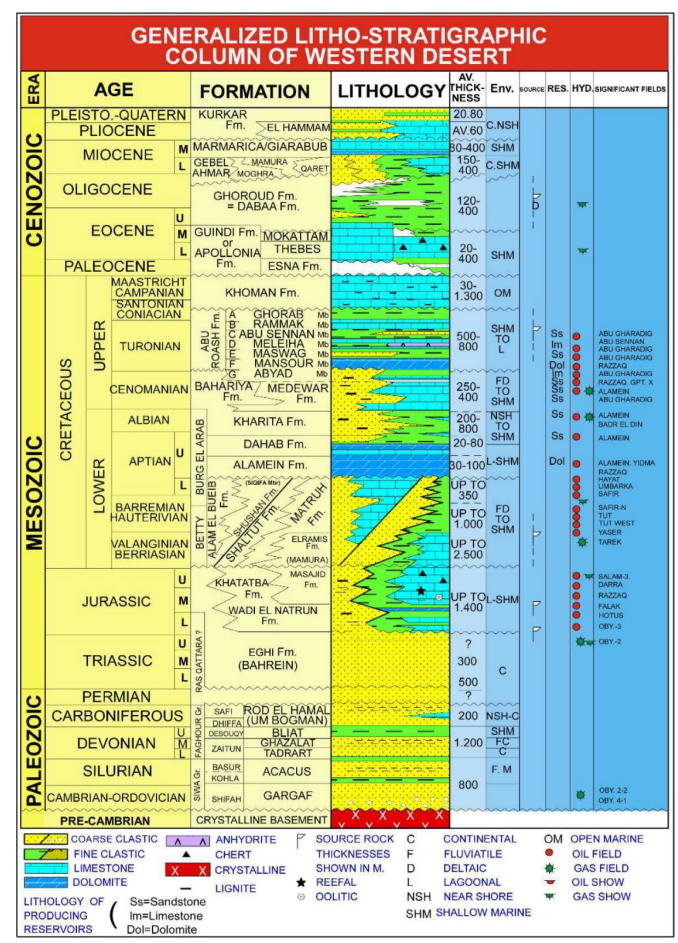

Fig. 2: The stratigraphic section in the northern Western Desert (Schlumberger, 1995).

The general structural and stratigraphical aspects of the Western Desert have been the subject of many studies, such as Amin (1961), Said (1962 and 1990), Norton (1967), Parker (1982), Meshref (1982), ElKhadragy and Sharaf (1994), Shalaby et al. (2000), Zein El-Din et al. (2001), El-Khadragy et al. (2010) and others.

The subsurface of the Western Desert of Egypt is characterized by a complicated system of Mesozoic rift basins that cover an area of approximately 200,000 $\mathrm{km}^{2}$ (Hantar, 
1990; Sehim, 1993; Bosworth et al., (2008, 2015) and Dolson et al., 2014) (Fig. 3).

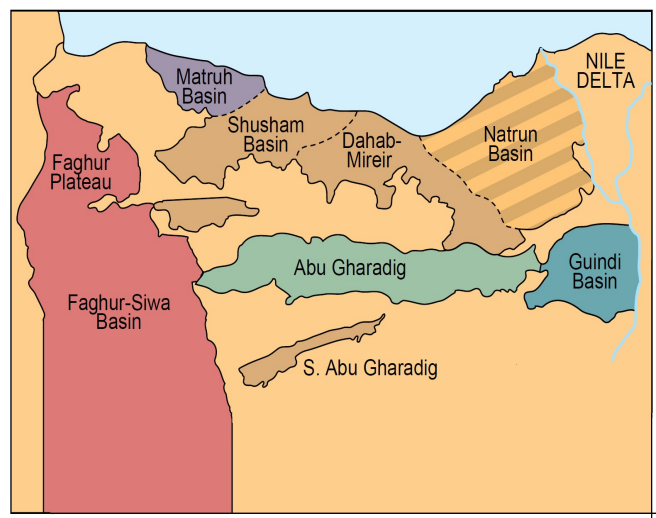

Fig. 3: Mesozoic and Cenozoic basins in the Western Desert and Sinai

(Abu Mostafa et al., 2018).

Figure (4) is a delineation map of basinal areas in the northern part of the Western Desert. The most important hydrocarbon producing areas in the western part of the Western Desert are the Faghur, Shoushan, and Abu Gharadig basins and their intervening higher platforms. Most of the basinbounding faults in this area strike eastwest to east-northeast/west-southwest, parallel to the old Neotethyan continental margin to the north. Northnorthwest/south-southeast to the northnortheast/south-southwest trending structures are also present and result in complicated regional basin geometries (Bosworth et al., 2015). These basins form a series of several discrete E-W to ENE-WSW, and NESW oriented half-graben basins that were initiated in the Jurassic and continued to subside through the Cretaceous, such as the Abu Gharadig, Alamein, Matruh, Faghur and Shoushan basins (Sultan and Halim, 1988; Emam et al., 1990; Taha, 1992; Moustafa, 2008; Bevan and Moustafa, 2012 and Bosworth et al., 2015).

In the Faghur basin, as in other parts of the northern Western Desert, the Alam El Bueib Formation consists of fine to coarse-grained sandstone with siltstone and subordinate gray shale (EGPC, 1992). It has a considerable thickness that has been subdivided into six units from bottom to the top: Alam El Bueib-6, Alam El Bueib-5, Alam El Bueib-4, Alam El Bueib-3, Alam El Bueib-2, and Alam El Bueib-1, whereas, the Alam El Bueib-3 unit itself was subdivided into six subunits: G, F, E, D, C and A (Abu El Naga, 1984). The Khatatba Formation consists of a thick shallow marine carbonaceous shale series, with interbedded sandstone, coal seams, and limestone streaks (Schlumberger, 1984). Paleozoic sediments are composed mainly of sandstone of various colours and siltstone with an abundance of limestone and shales in the upper part of the section (Fawzy and Dahi, 1992).

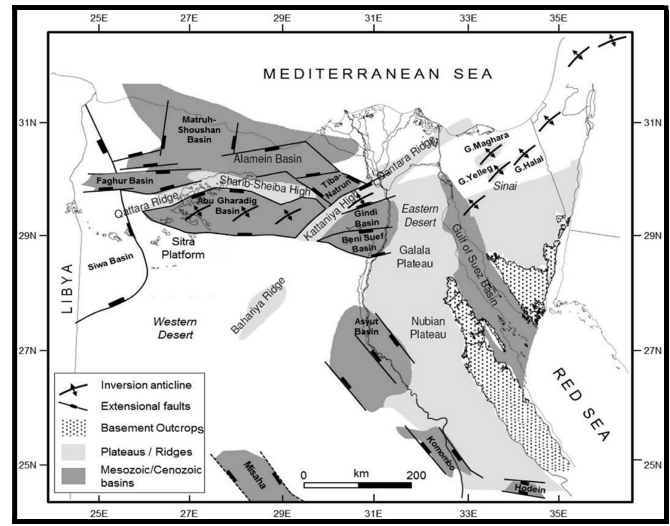

Fig. 4: Western Desert Basins Delineation Map

(Schlumberger, 1995).

\section{Material and methods}

Geochemical and thermal data analysis and modeling are used to predict the validity of the area for future oil and gas discoveries. Source rock evaluation is conducted through analysis of geochemical parameters including; total organic carbon (TOC), free hydrocarbons (S1), residual petroleum potential (S2), hydrogen index (HI), maximum temperature $\left(\mathrm{T}_{\max }\right)$ and vitrinite reflectance $\left(\% \mathrm{R}_{0}\right)$ of data from the Neith S-2X well for Alam El Bueib, Khatatba and Paleozoic source rocks. This is to predict hydrocarbon maturation and generation and construct 
thermal burial history and the timing of hydrocarbon generation.

Available geochemical data, measured by StratoChem for Khalda Petroleum Company, for this study comprised of 26 samples from Alam El Bueib source rocks, 12 samples from Khatatba source rock, and 9 samples of Paleozoic source rock (Table 1).
Moreover, Vitrinite reflectance $\left(\% \mathrm{R}_{\mathrm{o}}\right)$ analysis of 17 samples are measured (9 samples from Alam El Bueib source rocks, 3 samples from Khatatba source rock, and 5 samples from Paleozoic source rock).

Table (1): Geochemical data of Alam El Bueib, Khatatba and Paleozoic source rocks in Neith S-2X well, Faghur basin.

\begin{tabular}{|c|c|c|c|c|c|c|c|c|c|c|}
\hline \multirow{3}{*}{ Formation } & \multicolumn{2}{|c|}{ SAMPLE } & \multirow{3}{*}{$\begin{array}{l}\text { TOC } \\
w t \%\end{array}$} & \multirow{3}{*}{$\begin{array}{l}\text { S1 } \\
\mathrm{mg} / \mathrm{g}\end{array}$} & \multirow{3}{*}{$\begin{array}{l}\text { S2 } \\
\mathrm{mg} / \mathrm{g}\end{array}$} & \multirow{3}{*}{$\begin{array}{l}T_{\max } \\
d e g C\end{array}$} & \multirow{3}{*}{$\begin{array}{c}\text { S2/TOC } \\
\text { HI }\end{array}$} & \multirow{3}{*}{\begin{tabular}{|c|} 
S3/TOC \\
OI
\end{tabular}} & \multirow{3}{*}{$\begin{array}{c}\mathrm{S} 1 / \mathrm{S} 2+\mathrm{S} 3 \\
\mathrm{PI}\end{array}$} & \multirow{3}{*}{$\begin{array}{l}\mathbf{R}_{0} \\
\%\end{array}$} \\
\hline & \multicolumn{2}{|c|}{ DEPTH (ft) } & & & & & & & & \\
\hline & from & to & & & & & & & & \\
\hline \multirow{26}{*}{ 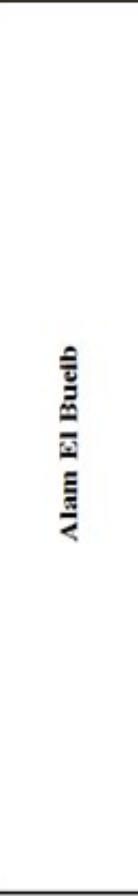 } & 9390 & 9400 & 0.48 & & & & & & & \\
\hline & 9490 & 9500 & 0.4 & & & & & & & \\
\hline & 9590 & 9600 & 0.35 & & & & & & & \\
\hline & 9720 & 9730 & 0.68 & 0.12 & 0.23 & 428 & 34 & 65 & 0.34 & 0.68 \\
\hline & 10500 & 10510 & 0.27 & & & & & & & \\
\hline & 10870 & 10880 & 0.41 & & & & & & & \\
\hline & 11040 & 11050 & 1.18 & 0.2 & 1.34 & 431 & 114 & 64 & 0.13 & 0.58 \\
\hline & 11230 & 11240 & 1.29 & 0.22 & 1.23 & 430 & 95 & 43 & 0.15 & 0.68 \\
\hline & 11340 & 11350 & 0.97 & 0.24 & 0.68 & 430 & 70 & 58 & 0.26 & \\
\hline & 11390 & 11400 & 0.72 & 0.2 & 0.42 & 434 & 58 & 68 & 0.32 & \\
\hline & 11490 & 11500 & 0.86 & 0.17 & 0.57 & 430 & 66 & 36 & 0.23 & \\
\hline & 11840 & 11850 & 1.19 & 0.16 & 1.04 & 432 & 87 & 39 & 0.13 & 0.62 \\
\hline & 11940 & 11950 & 0.69 & 0.12 & 0.54 & 435 & 78 & 83 & 0.18 & \\
\hline & 12240 & 12250 & 0.9 & 0.18 & 0.57 & 433 & 63 & 106 & 0.24 & 0.86 \\
\hline & 12460 & 12470 & 0.53 & 0.16 & 0.14 & 443 & 26 & 138 & 0.53 & \\
\hline & 12690 & 12700 & 0.62 & 0.17 & 0.37 & 436 & 60 & 140 & 0.31 & \\
\hline & 12850 & 12860 & 0.5 & 0.16 & 0.19 & 409 & 38 & 84 & 0.46 & \\
\hline & 12890 & 12900 & 6.39 & 0.32 & 4.3 & 437 & 67 & 10 & 0.07 & 0.89 \\
\hline & 12990 & 13000 & 0.76 & 0.18 & 0.37 & 450 & 49 & 63 & 0.33 & \\
\hline & 13090 & 13100 & 0.8 & 0.22 & 0.4 & 438 & 50 & 118 & 0.35 & 1.07 \\
\hline & 13190 & 13200 & 0.8 & 0.18 & 0.32 & 449 & 40 & 129 & 0.36 & \\
\hline & 13290 & 13300 & 1.05 & 0.24 & 0.65 & 444 & 62 & 109 & 0.27 & \\
\hline & 13390 & 13400 & 1.05 & 0.23 & 0.67 & 443 & 64 & 63 & 0.26 & 0.85 \\
\hline & 13440 & 13450 & 0.89 & 0.16 & 0.35 & 438 & 39 & 52 & 0.31 & \\
\hline & 13790 & 13800 & 0.39 & & & & & & & \\
\hline & 14020 & 14030 & 2.52 & 0.38 & 2.43 & 442 & 96 & 33 & 0.14 & 0.77 \\
\hline \multirow{12}{*}{ 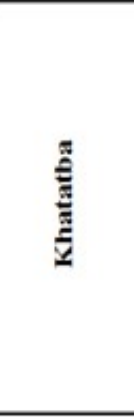 } & 14270 & 14280 & 0.65 & 0.1 & 0.19 & 391 & 29 & 34 & 0.34 & \\
\hline & 14290 & 14300 & 0.56 & 0.11 & 0.15 & 363 & 27 & 70 & 0.42 & \\
\hline & 14330 & 14340 & 0.41 & & & & & & & \\
\hline & 14380 & 14390 & 4.75 & 0.25 & 4.6 & 454 & 97 & 16 & 0.05 & 1.05 \\
\hline & 14390 & 14400 & 6.09 & 0.28 & 6.08 & 451 & 100 & 19 & 0.04 & \\
\hline & 14400 & 14410 & 7.04 & 0.25 & 6.85 & 453 & 97 & 9 & 0.04 & \\
\hline & 14410 & 14420 & 30.09 & 0.48 & 26.41 & 450 & 88 & 6 & 0.02 & 1.09 \\
\hline & 14420 & 14430 & 12.18 & 0.53 & 15.09 & 453 & 124 & 9 & 0.03 & \\
\hline & 14430 & 14440 & 8.25 & 0.47 & 9.93 & 451 & 120 & 24 & 0.05 & \\
\hline & 14450 & 14460 & 9.09 & 0.45 & 12.19 & 450 & 134 & 17 & 0.04 & \\
\hline & 14460 & 14470 & 9 & 0.51 & 11.26 & 454 & 125 & 13 & 0.04 & \\
\hline & 14490 & 14500 & 8.18 & 0.53 & 12.68 & 449 & 155 & 12 & 0.04 & 1.02 \\
\hline \multirow{9}{*}{ 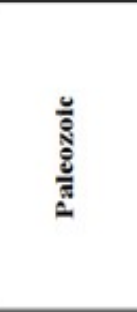 } & 14570 & 14580 & 4.83 & 0.4 & 6.57 & 449 & 136 & 11 & 0.06 & 1.09 \\
\hline & 14590 & 14600 & 3.04 & 0.32 & 3.99 & 452 & 131 & 13 & 0.07 & \\
\hline & 14690 & 14700 & 2.2 & 0.22 & 1.81 & 451 & 82 & 27 & 0.11 & 1.1 \\
\hline & 14740 & 14750 & 0.53 & 0.07 & 0.29 & 406 & 55 & 87 & 0.19 & \\
\hline & 14790 & 14800 & 1.66 & 0.14 & 1.25 & 452 & 75 & 27 & 0.1 & 1.05 \\
\hline & 14840 & 14850 & 1.95 & 0.14 & 1.74 & 452 & 89 & 12 & 0.07 & \\
\hline & 14890 & 14900 & 1.92 & 0.13 & 1.67 & 449 & 87 & 17 & 0.07 & 0.97 \\
\hline & 14940 & 14950 & 0.81 & 0.07 & 0.45 & 464 & 56 & 32 & 0.13 & 0.98 \\
\hline & 14970 & 14980 & 0.67 & 0.06 & 0.35 & 467 & 52 & 36 & 0.15 & \\
\hline
\end{tabular}




\section{Results and Discussion}

\section{Source Rock Evaluation}

\section{Organic matter richness (TOC wt.\%)}

Source rock richness is determined by measuring the total organic carbon (TOC) present in a rock (Law, 1999). The TOC values of the Alam El Bueib source rocks range from 0.27 to 6.39 wt. $\%$ with an average value of 1.03 wt.\%, while in Khatatba source rock, they range from 0.41 to 30.09 wt.\% with an average value of 8.02 wt. $\%$. As for the Paleozoic source rock, they range from 0.53 to 4.83 wt. $\%$ with an average value of $1.96 \mathrm{wt} \%$. Using the classification of Peters (1986), it is clear that most of Alam El Bueib source rocks are considered fair to good source rock, especially Alam El Bueib-3A and Alam El Bueib-3C units but Alam El Bueib-6 unit is very good source rock. The Khatatba source rock is very good to fair source rock, while the Paleozoic rocks are considered as fair to very good source rock (Fig. 5). Such results match those of Abd-El Gawad, et al. (2015), who used fewer samples.

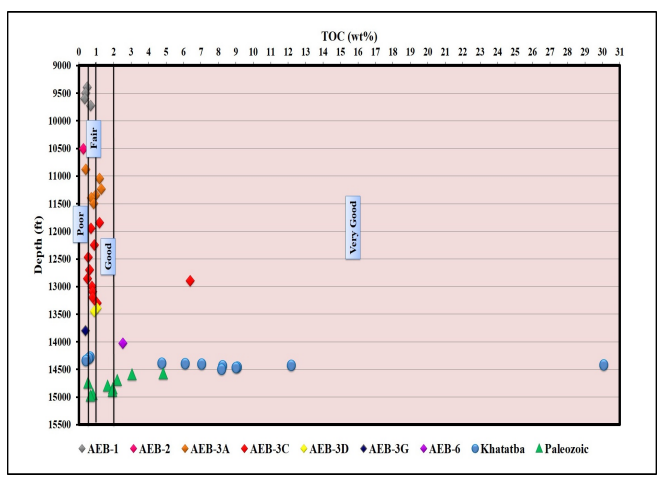

Fig. 5: Total organic carbon richness (TOC) of Alam El Bueib, Khatatba and Paleozoic source rocks in Neith S-2X well, Faghur basin (Peters, 1986).

\section{Types of organic matter}

According to Hollander et al. (1991), the organic matter content must be enough to establish a continuous kerogen network, which leads to the full connectivity of organic matter in the rock. Therefore, the quantity and type of organic matter are determined by a visual study of kerogen isolates and Rock-Eval Pyrolysis. The relationship between the Hydrogen Index (HI) and Oxygen Index (OI) of the used samples indicates that Alam El Bueib source rocks are characterized by type (III) kerogen. The Khatatba and Paleozoic source rocks, on the other hand, are type III kerogen with the input of kerogen type II (Fig. 6).

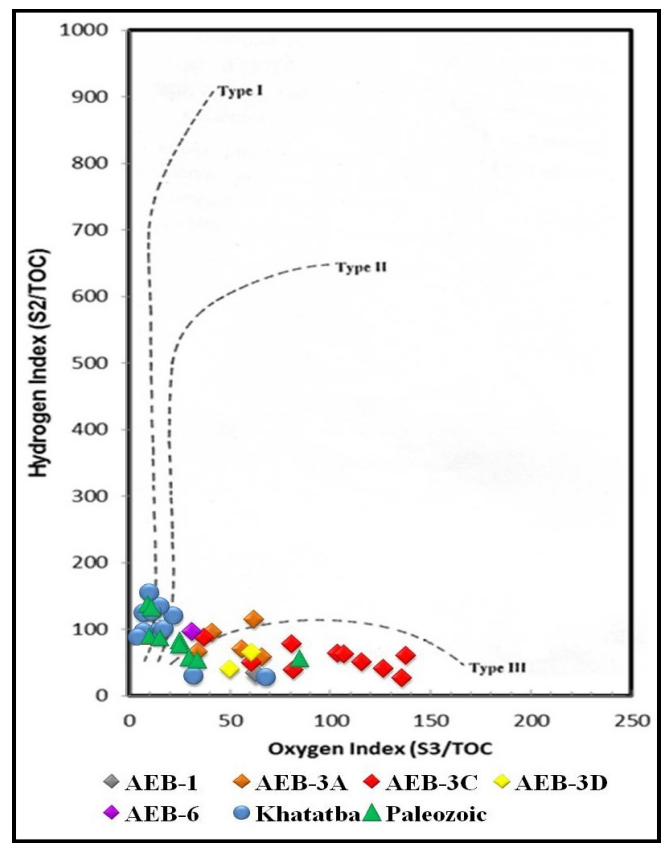

Fig. 6: Modified Van Krevelen (1961) type diagram showing kerogen type of Alam El Bueib, Khatatba and Paleozoic source rocks in Neith S-2X well, Faghur basin (Espitalié et al., 1977).

Hydrogen Index (HI) values of different source rocks indicate that they are mainly of kerogen type III, where the HI values range from 34 to 114 $\mathrm{mg} / \mathrm{g}$ with an average value of 62.8 $\mathrm{mg} / \mathrm{g}$ for Alam El Bueib source rocks, from 27 to $155 \mathrm{mg} / \mathrm{g}$ with an average value of $99.64 \mathrm{mg} / \mathrm{g}$ for Khatatba source rock and from 52 to $136 \mathrm{mg} / \mathrm{g}$ with an average value of $84.78 \mathrm{mg} / \mathrm{g}$ for Paleozoic source rock. These results indicate the capability of these source rocks to produce gas with minor oil using Waples's (1985) classification (Fig. 7). 


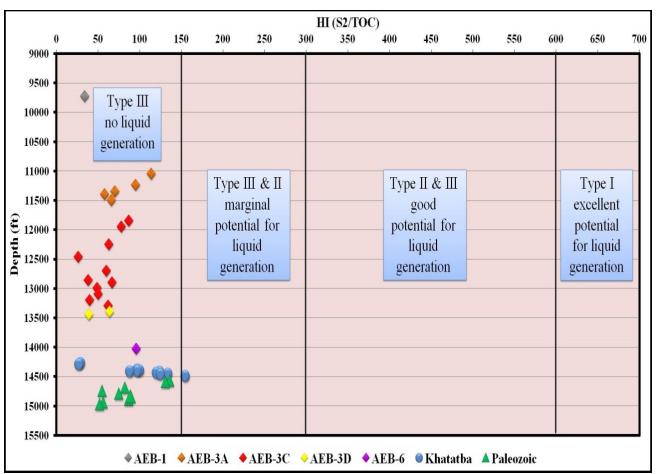

Fig. 7: Hydrocarbon index (HI) of Alam El Bueib, Khatatba and Paleozoic source rocks in Neith S-2X well, Faghur basin (Waples, 1985).

\section{Hydrocarbon generation and migration}

The free hydrocarbon (S1) represents the hydrocarbon vaporized and driven off from the sample at low temperature to about $300^{\circ} \mathrm{C}$ and is measured in $\mathrm{mg} \mathrm{HC/g}$ rock. S1 values range from 0.12 to $0.38 \mathrm{mg} / \mathrm{g}$ with an average value of $0.2 \mathrm{mg} / \mathrm{g}$ for Alam El Bueib source rocks and from 0.1 to 0.53 $\mathrm{mg} / \mathrm{g}$ with an average value of 0.36 $\mathrm{mg} / \mathrm{g}$ for Khatatba source rock and from 0.06 to $0.4 \mathrm{mg} / \mathrm{g}$ with an average value of $0.17 \mathrm{mg} / \mathrm{g}$ for Paleozoic source rock. According

to Peters's (1986) classification these values indicate a poor potential source rock for hydrocarbon generation for most studied rocks. However, the Khatatba source rock shows signs of fair potential for hydrocarbon generation (Fig. 8).

The residual petroleum potential (S2) represents the amount of hydrocarbons generated through thermal cracking (at $300-550{ }^{\circ} \mathrm{C}$ ) of the contained kerogen (Waples, 1985). The values of S2 of the Alam El Bueib source rocks range from 0.23 to 4.3 $\mathrm{mg} / \mathrm{g}$ with an average value of 0.84 $\mathrm{mg} / \mathrm{g}$, while for the Khatatba source rock range from 0.15 to $26.41 \mathrm{mg} / \mathrm{g}$ with an average value of $9.58 \mathrm{mg} / \mathrm{g}$ and for the Paleozoic source rock they range from 0.29 to $6.57 \mathrm{mg} / \mathrm{g}$ with an average value of $2.01 \mathrm{mg} / \mathrm{g}$. These values indicate that most of Alam El Bueib and Paleozoic source rocks have poor hydrocarbon potentiality, while the Khatatba source rock has fair to very good hydrocarbon potentiality according to Peters's (1986) classification (Fig. 9).

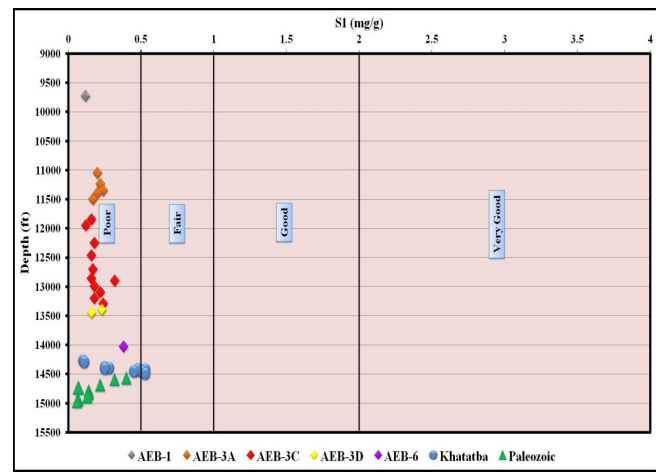

Fig. 8: Free hydrocarbons (S1) of Alam El Bueib, Khatatba and Paleozoic source rocks in Neith S-2X well, Faghur basin (Peters, 1986).

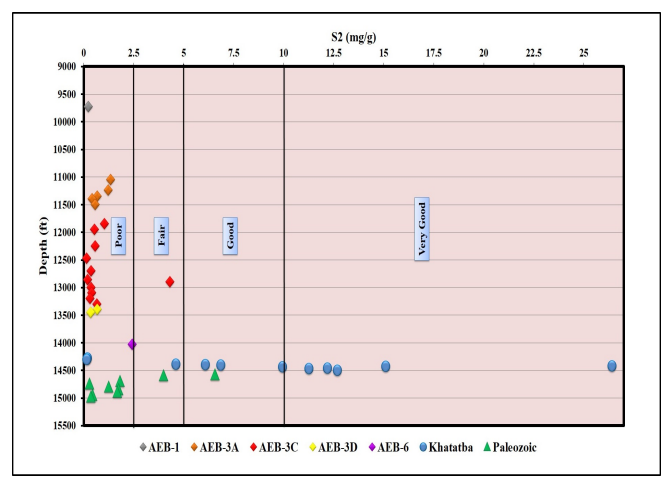

Fig. 9: Residual petroleum potential (S2) of Alam El Bueib, Khatatba and Paleozoic source rocks in Neith S-2X well, Faghur basin (Peters, 1986).

\section{Maturation of organic matter}

Vitrinite reflectance $\left(\% \mathrm{R}_{0}\right)$ is a widely used indicator for reflecting the thermal maturity of kerogen, because it extends over a longer maturity range than any other indicator (Waples, 1985). The $\% R_{0}$ values of most of the Alam El Bueib, Khatatba, and Paleozoic source rocks indicate that theses source rocks fall within the mature stage (oil generate), as the values range from 0.58 to $1.07 \%$ with an average value of 0.78 $\%$ for Alam El Bueib source rock, from 
$1.02 \%$ to $1.09 \%$ with an average value of $1.05 \%$ for Khatatba source rock and from 0.97 to $1.1 \%$ with an average value of $1.04 \%$ for Paleozoic source rock (Fig. 10).

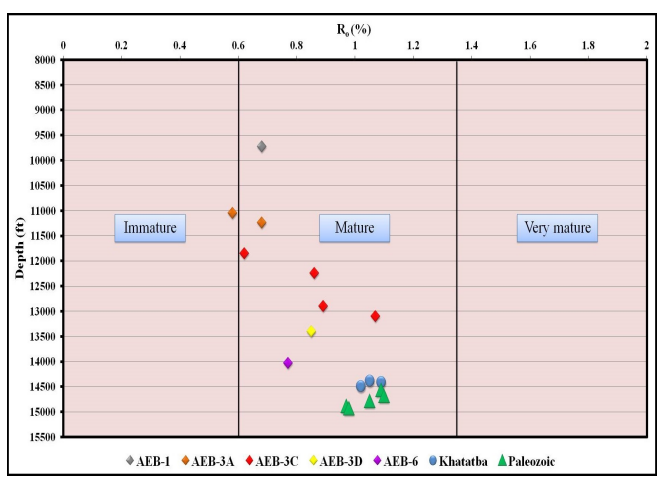

Fig. 10: Vitrinite reflectance (\%Ro) of Alam El Bueib, Khatatba and Paleozoic source rocks in Neith S-2X well, Faghur basin (Waples, 1985).

The maximum temperature $\left(T_{\max }\right)$ is defined as the pyrolysis temperature at which the maximum amount of hydrocarbon is released by kerogen (Espitalié et al., 1977). $T_{\max }$ increases linearly with the degree of maturation of the organic matter (Barker, 1974; Espitalié et al., 1977). The $T_{\max }$ values variation depends not only on maturity but also may be influenced by the kerogen type (Hunt, 1996). The type of organic matter (kerogen) is considered the second most important parameter in evaluating the source rock. Based on pyrolysis data, kerogen classification diagrams were constructed using the $\mathrm{HI}$ versus $T_{\max }$ plot as carried out by previous workers (e.g., Mukhopadhyay et al., 1995) was used to determine the kerogen type and maturity. According to Espitalié et al., (1985) classification, these results indicate that most of Alam El Bueib source rocks are characterized by type III kerogen and are located in mature stage within oil generation specially Alam El Bueib-3A, Alam El Bueib-3C, and Alam El Bueib-6 source rocks, while the rest still in immature stage (Fig. 11). The Khatatba and Paleozoic source rocks, on the other hand, are characterized by type III kerogen with inputs of kerogen type II, falling within the mature range to generate oil and condensate/gas window. This is in agreement with Abd-El Gawad, et al. (2015) results, which concluded that both the Jurassic and Paleozoic source rocks in Neith $\mathrm{S}-2 \mathrm{X}$ are mature and can generate oil.

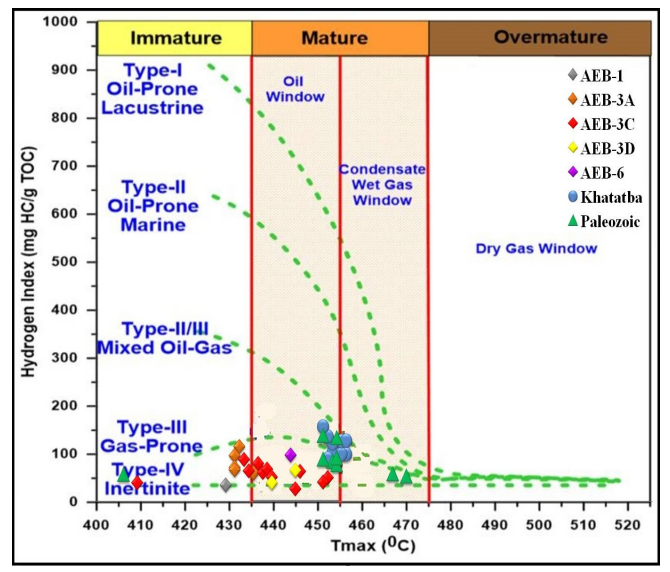

Fig. 11: Plot of hydrogen index (HI) versus maximum temperature $\left(T_{\max }\right)$ for Alam El Bueib, Khatatba and Paleozoic source rocks in Neith S-2X well, Faghur basin (Espitalié et al., 1985).

\section{Burial, thermal histories and hydrocarbon zones of the study area}

The thermal burial history and maturity models of the studied source rocks from the studied well were constructed using PetroMod 11 software. The data needed to construct the thermal subsidence history at source rock tops or true stratigraphic thickness, geologic age of the time-rock unit, geothermal gradient, and magnitude of erosion and the non-deposition periods or hiatus.

In this study, the analysis of the influence of the tectonic evolution in the basin on the heat-flow distribution through time was made using 1D modeling of data from Neith S-2X well, Faghur basin. Heat flow is a vital input parameter in basin modeling, but it is not easy to define this value for the 
geological past. Therefore, the reconstruction of the thermal history of the basin is always simplified and is usually calibrated against profiles of maturity (e.g., vitrinite reflectance and temperature).

Figure 12 shows the temperature gradients in Faghur basin. The temperature values increase systematically with depth from surface temperature. Figure 13 indicates that sediments from the studied well reached maximum temperatures at Neogene time. During the burial history of the area, the source rock suffered from increasing temperature. The reconstructed burial histories of rocks in the studied well by time-depth history plots after applying the temperature effects show a close relationship to the basin tectonic evolution and the distribution of temperature through the basin. It also shows that the temperature values increase systematically with depth from surface temperature.

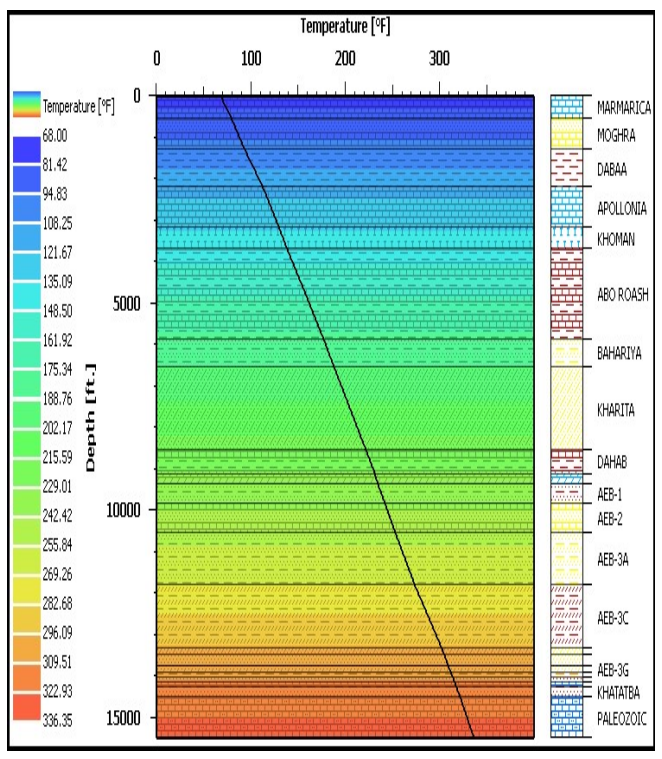

Fig. 12: Modeled burial and temperature gradient of Alam El Bueib, Khatatba and Paleozoic source rocks in Neith S-2X well, Faghur basin.

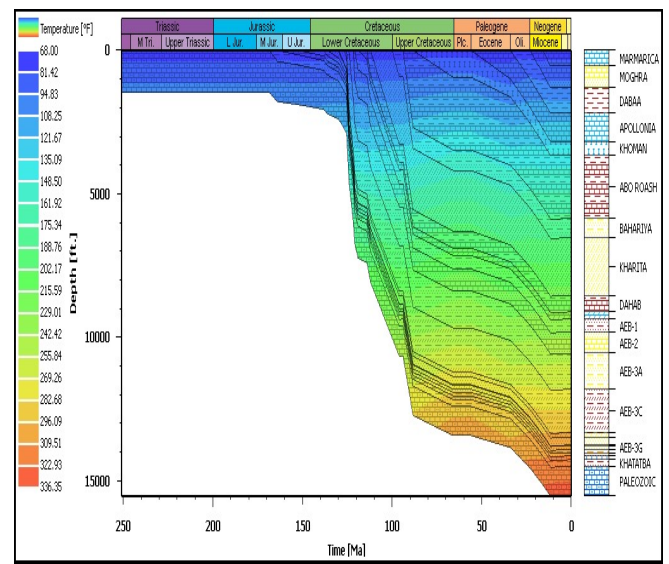

Fig. 13: Thermal burial history and temperature fitting Alam El Bueib, Khatatba and Paleozoic source rocks in Neith S-2X well, Faghur basin.

The timing of hydrocarbon generation may be determined more directly using kinetic parameters. The oil window in a well indicates the hydrocarbon generation potentialities of the source rock. The 1D PetroMod program has been used to construct the thermal burial history models (Fig. 14) and locate the oil window for each source rock as an indication of the hydrocarbon generation of the study area. The model shows the depth and the age of oil and gas generation for the studied source rocks in Neith S-2X well (Table 2).

The timing of oil and gas generation of the present rocks varies from one source rock to another (Fig. 14). The Early Cretaceous Alam El Bueib source rocks were able to generate oil during the Early/Late Cretaceous to Neogene times, specially Alam El Bueib-3A, Alam El Bueib-3C, and Alam El Bueib6. On the other hand, the Jurassic source rocks might have generated oil during Early Cretaceous to Miocene. They might have also begun to condensate gas during Miocene and continued to do so until now. The Paleozoic source rock may have generated oil during Early Cretaceous to Paleocene and generated condensate gas from Paleocene onward (Fig. 14). Such results are in agreement 
with estimations driven by Abd-El Gawad et al. (2015) who stated that the Safa and Paleozoic source rocks in Faghur Basin entered the oil window during Early to Middle Cretaceous and were able to generate oil starting from Early Late Cretaceous and continued to do so until the present time.

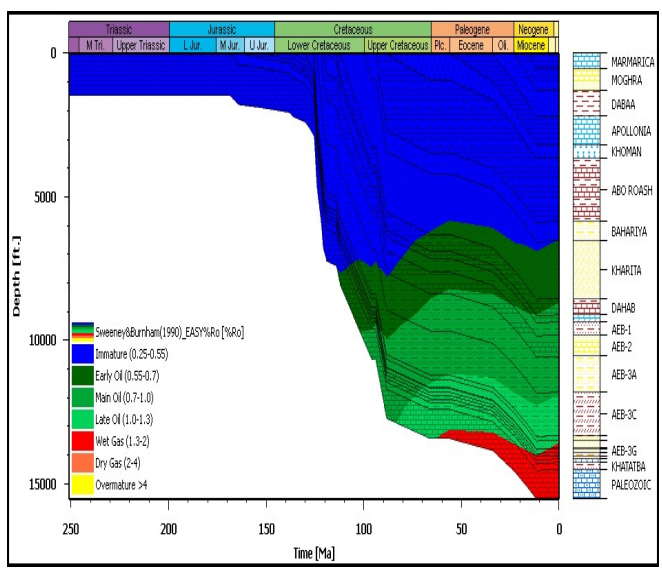

Fig. 14: The burial history and hydrocarbon zones of Alam El Bueib, Khatatba and Paleozoic source rocks in Neith S-2X well, Faghur basin.

Table (2): Depth and time of the hydrocarbon generation of Alam El Bueib, Khatatba and Paleozoic source rocks in Neith S-2X well, Faghur basin.

\begin{tabular}{|c|c|c|c|c|c|}
\hline Well & Source Rocks & $\begin{array}{c}\text { Depth of Oil } \\
\text { Generation } \\
\text { (ft) }\end{array}$ & $\begin{array}{c}\text { Onset of Oil } \\
\text { Generation } \\
\text { (Malp) }\end{array}$ & $\begin{array}{c}\text { Depth of Gas } \\
\text { Generation } \\
\text { (ft) }\end{array}$ & $\begin{array}{c}\text { Onset of Gas } \\
\text { Generation } \\
\text { (Malp) }\end{array}$ \\
\hline \multirow{5}{*}{ 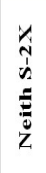 } & Alam El Bueib-3A & 7641 & 91.03 & Not Reached & ................... \\
\hline & Alam El Bueib-3C & 7200 & 103.06 & Not Reached & $\ldots \ldots \ldots \ldots . . .$. \\
\hline & Alam El Bueib-6 & 7361 & 107.21 & Not Reached & ………........ \\
\hline & Khatatba & 7507 & 108.73 & 13665 & 22.08 \\
\hline & Paleozoic & 7568 & 112.98 & 13402 & 62.87 \\
\hline
\end{tabular}

\section{Conclusions}

Some of the Mesozoic and Paleozoic formations in the Faghur basin (Western Desert of Egypt) are important oil and gas source rocks. Geochemical characterization of the Alam El Bueib, Khatatba and Paleozoic rocks and basin modeling using data from three source rocks have led to the following conclusions:
1. The Lower Cretaceous Alam El Bueib source rocks constituted a mature source rock with good capability for generating gas with minor oil and entered the oil window during the Early/Late Cretaceous to Neogene times, specially Alam El Bueib-3A, Alam El Bueib-3C, and Alam El Bueib6.

2. The Jurassic Khatatba source rock bears a mature source rock and has very good to fair generating capability for generating gas with minor oil and entered the oil window during Early Cretaceous to Miocene times, and it lies within condensate gas during Miocene and continues to do so until now.

3. The Paleozoic source rock has mature source rock and fair to very good potential to generate gas with a low amount of oil and entered the oil window during Early Cretaceous to Paleocene and condensate gas from Paleocene.

4. Geochemical analysis and basin modeling indicate that Khatatba source rock is much more effective for hydrocarbon generation than the Alam El Bueib and Paleozoic source rocks.

\section{References}

Abd-El Gawad, E.A., Elsheikh, A., Afify, W., and Salem, T., 2015. Petroleum System evaluation of Jurassic and Paleozoic sections in Faghur Basin, North Western Desert, Egypt. International Journal of Scientific Engineering and Applied Science (IJSEAS) Vol. 1, p. 2395-3470.

Abd-El-Gawad, E. A., Fathy M., and Abd-El-Dayem, Kh., 2016. Integratred characterization of Desouqy reservoir Rock in Faghur Siwa Basin, Western-Desert, Egypt. International Journal of Innovative Science, Engineering \& Technology (IJISET) Vol. 3, p. 2348-7968. 
Abd-El-Gawad, E. A., Mohamed, F. G., Mostafa, M. L., Doaa, A. M., Mostafa, G. T., and Amr, M. S., 2019. Burial and thermal history simulation of the subsurface Paleozoic source rocks in Faghur basin, north Western Desert, Egypt: Implication for hydrocarbon generation and expulsion history. Egyptian Journal of Petroleum 28 (2019). Elsevier, p. 261-27.

Abdou A.A., Shehata M.G., and Kassab M.A.M., 2009. Petrography and probable reservoir potentiality of subsurface Jurassic rocks at $\mathrm{Abu}$ Gharadiq Basin and Shoushan Subbasin, north Western Desert, Egypt. Aust J Basic Appl Sci 3:1206-1222.

Abu El Naga, M., 1984. In Paleozoic and Mesozoic depocenters and hydrocarbon generating areas, northern Western Desert (Vol. 8, pp. 269-287). Paper presented at the 7th Petroleum and Exploration Seminar, Egyptian General Petroleum Corporation, Cairo.

Abu Mostafa, A., Abu Khadrah, A.M., and Refaat, A.A., 2018. Impact of diagenesis on reservoir quality evolution of the late Cenomanian Abu Roash "G" Member in the Sitra Field, North Western Desert, Egypt. Marine and Petroleum Geology 95 (2018). Elsevier, pp. 255-264.

Amin, M.S., 1961. Subsurface features and oil prospects of the Western Desert, Egypt. 3Prd Arab. Petrol. Cong., Alexandria, Egypt, Vol. 2, 8 p.

Barakat, M.G., 1982. General Review of the Petroliferous Provinces of Egypt. Petroleum and Gas Project, Cairo Univ./M.I.T. Technology Planning Program.

Barker, C., 1974. Pyrolysis techniques for source-rock evaluation. American Association of Petroleum Geologist Bulletin, 58, 2349_2361.
Bevan, T.G., and Moustafa, A.R., 2012. Inverted rift-basins of northern Egypt. In: Roberts, D.G., Bally, A.W. (Eds.), Regional geology and tectonics: Phanerozoic rift systems and sedimentary basins, vol. 1BElsevier, pp. 483e507.

Bosworth, W., Abrams, M.A., Drummond, M., and Thompson, M., 2015. Jurassic rift initiation source rock in the Western Desert, Egypt - relevance to exploration in other continental rift systems.

Bosworth, W., El-Hawat, A.S., Helgeson, D.E., and Burke, K., 2008. Cyrenaican "shock absorber" and associated inversion strain shadow in the collision zone of northeast Africa: Geology, v. 36, p. 695-698.

Carlos R., Rafaela M., Karl R., and Albert P., 2001. Facies-related diagenesis and multiphase siderite cementation and dissolution in the reservoir sandstones of the Khatatba Formation, Egypt's Western Desert. J Sediment Res 71. 459-472.

Dolson, J.C., Pemberton, S.G., Hafizov, S., Bratkova, V., Volfovich, E., and Averyanova, I., 2014. Giant Incised Valley Fill and Shoreface Ravinement Traps, Urna, UstTeguss and Tyamkinskoe Field Areas, Southern West Siberian Basin, Russia: AAPG Annual Convention and Exhibition, Houston, Texas, April 6-9, 2014, Search and Discovery Article \#10634 (2014). Website accessed June 2018.

EGPC (Egyptian General Petroleum Corporation), 1992. Western Desert, oil and Gas fields, a comprehensive overview. EGPC, 11th Petrol. Expl. and Prod. Conf., Cairo, 431 p.

El-Dakkak, M.W., 1988. Geological studies of subsurface Paleozoic strata of northern Western Desert, 
Egypt. Journal of African Earth Sciences 7, 103e111.

El-khadragy, A.A., and Sharaf, M., 1994. Inferring the basement structure of northwestern Desert, using potential field data. Bull. Fac. Sci., Zagazig Univ., 16(2): 92-110.

El-khadragy, A.A., Saad M.H., and Azab, A., 2010. Crustal modeling of south Sitra area, north Western Desert, Egypt using Bouguer gravity data. Journal of Applied Science Research, 61(1): 22-27.

El-Mansey, I.M., Shehata, M.G., Massoud, M.A., and Awad, S.A. 2004. Geochemical Studies on Subsurface Paleozoic Sediments from some Wells in Siwa-Faghur Basin, Western Desert, Egypt. Egyptian Journal of Petroleum, v. 13(2), p. 91-106.

Emam, A., Bishopp, D.J., Milsom, J., and Dunderdale, I., 1990. The structural setting of the central Western Desert, Egypt. In: Proceedings of 10th Egyptian General Petroleum Corporation Exploration and Production Conference, vol. 2, pp. 30e70.

Espitalié, J., La Porte, J.L., Madec, M., Marquis, F., Leplat, P., Paulet, J., and Boutefeu, A., 1977. Methode rapide de caracterisation des roches mere de leur potential petrolier of de leur degree evolution. Rev. de 1. Inst. France Petrol., vol. 32 (1), p. $32-42$.

Espitalié, J., Deroo, G., and Marquis, F., 1985. Rock-Eval pyrolysis and its application. Inst. Fr. Preprint, 33578: 72.

Fawzy, A., and Dahi, M., 1992. In Regional geological evaluation of the Western Desert, Egypt (pp. 111149). Paper presented at the Geology of the Arab World, Cairo University.

Hanter, G., 1990. North Western Desert. In: Said, R. (eds.). The geology of
Egypt. A. A. Balkema, Rotterdam, Netherlands. pp. $293-319$.

Hollander, D.J., Bessereau, G., Belin, S., Huc, A.Y., and Houzay, J.P., 1991. Organic matter in the early Torcian shales, Paris Basin, France: aresponse to environmental changes. Rev. De 1 Inst. France Petrol., Vol.46, pp. 543-562.

Hunt, J.M., 1996. Petroleum geochemistry and geology. 2nd ed. New York, W.H. Freeman and Company, $743 \mathrm{p}$.

Keeley, M.L., 1989. The Paleozoic history of the Western Desert of Egypt. Basin Research 2, 35e48.

Law, C.A., 1999. Evaluating Source Rocks. In: Beaumont E. A., and Foster N.H. Treatise of Petroleum Geology / Handbook of Petroleum Geology: Exploring for Oil and Gas Traps. chapter 6.

Meshref, W. M., 1982. Regional Structural Setting of Northern Egypt. EGPC 6th Explor. Sem., Cairo, 11p.

Moustafa, A.R., 2008. Mesozoice Cenozoic basin evolution in the northern Western Desert of Egypt. In: Salem, M., El-Arnauti, A., Saleh, A. (Eds.),. In: 3rd Symposium on the Sedimentary Basins of Libya, vol. 3. The Geology of East Libya, pp. 29-46.

Mukhopadhyay, P.K., Wade, J.A., and Kruge, M.A., 1995. Organic facies and maturation of Jurassic/Cretaceous rocks, and possible oil-source rock correlation based on pyrolysis of asphaltenes, Scotion Basin, Canada, Org. Geochem. 22 (1995) 85-104.

Norton, P., 1967. Rock stratigraphic nomenclature of the Western Desert. Internal report, Pan American Oil Co., Cairo, 557 p.

Parker, J. R., 1982. Hydrocarbon Habitat of the Western Desert, 
Egypt. EGPC, 6th Explor. Sem., Cairo.

Peters, K.E., 1986. Guidelines for evaluating petroleum source rock using programmed pyrolysis. AAPG Bull., Vol. 70, pp. 318-329.

Said, R., 1962. The geology of Egypt. Elsevier Publ. Co., Amsterdam, Oxford and New York, $277 \mathrm{p}$.

Said, R., 1990. Cretaceous paleogeographic maps. In: Said, R. (Ed.), The Geology of Egypt.

Schlumberger, 1984. Well evaluation conference, Egypt. Geology of Egypt, pp. 1-64.

Schlumberger, 1995. Well Evaluation Conference, Egypt. Schlumberger Technical Editing Services, Chester. pp. 58-66.

Sehim, A., 1993. Cretaceous tectonic in Egypt. Egypt. J. Geol. 37-1, 335372.

Shalaby, M.R., Abdel Hamid A.T., and Abu shady A., 2000. "Structural setting and sedimentary environments using dipmeter analysis of some Jurassic reservoirs, North Western Desert, Egypt", 5th International Conf., Geology of the Arab World, Cairo Univ., Egypt, pp: 217-220.

Shalaby M.R., Hakimi M.H., and Abdullah W.H., 2013. Modeling of gas generation from the Alam ElBueib source rock in the Shoushan
Basin, northern Western Desert of Egypt. Int J Earth Sci 102: 319332.

Sultan, N., and Abd El-Halim M., 1988. Tectonic framework northern Western Desert, Egypt and its effect on hydrocarbon accumulations. $9^{\text {th }}$ Explo. Conf., EGPC, Cairo, Egypt, $31 \mathrm{p}$.

Taha, M.A., 1992. In Mesozoic rift basins in Egypt. Their southern extension and impact on future exploration (Vol. 2, pp. 1-19). Paper presented at the Proceeding of $11^{\text {th }}$ Exploartaion and Production Conference, Egyptian General Petroleum Corporation, Cairo. November.

Van Krevelen, D.W., 1961. Coal Typology Chemistry Physics Constitution, Elsevier Publishing Company.

Waples, D.W., 1985. Geochemistry in petroleum exploration. International Human Resources Development Corporation, Boston, $232 \mathrm{p}$.

Zein El-Din, M.Y., Abd El-Gawad, E.A., El-Shayb, H.M., and Haddad, I.A., 2001. Geological studies and hydrocarbon potentialities of the Mesozoic rocks in Ras Kanayis onshore area, North Western Desert, Egypt. Annals of the Geological Survey of Egypt, XXIV, 115-134. 